\title{
The phycologist Pierre Compère: his contribution to cyanobacterial studies
}

\author{
Stjepko Golubic ${ }^{1,2}$ \& Annick Wilmotte ${ }^{1,3, *}$
}

${ }^{1}$ Centre for Protein Engineering, Bacterial physiology and genetics, Institute of Chemistry B6, University of Liège, BE-4000 Liège, Belgium

${ }^{2}$ Department of Biology, Boston University, Boston, MA 02215, USA

${ }^{3}$ Member of the Editorial Board of Plant Ecology and Evolution

*Author for correspondence: awilmotte@ulg.ac.be

\begin{abstract}
At the occasion of the $80^{\text {th }}$ birthday of Pierre Compère, his rich career as a phycologist and cyanobacteriologist is placed in the context of the advances of the scientific theories, the evolution of the cyanobacterial taxonomy and the nomenclatural discussions linked to the utilization of two different Codes of nomenclature.
\end{abstract}

Key words - Compère, blue-green algae, cyanobacteria, cyanophyceae, taxonomy, nomenclature.

We are celebrating the $80^{\text {th }}$ birthday of the Belgian phycologist Pierre Compère. This reminds that some research disciplines have birth-like starts, growth and maturation, just like the personalities that become involved and contribute to them. We are referring to Pierre Compère's work on algae and blue-green algae (as cyanobacteria were called then). Indeed, he was among the few scientists who took these organisms seriously and engaged in the frustrating work with this group of colourful but variable bacteria.

As very well described in the biography written by Fabri \& Symoens (2000), Pierre Compère was born in 1934 in Aywaille, Belgium, and got a degree in Botanical Sciences at the University of Liège. He had a long and successful career in phycology with a major contribution to systematics and ecology of algae and cyanobacteria. He started his botanical studies in 1959 in Africa, as a part of a survey of flora and vegetation of the lower Congo region, carried out by the National Institute for Agriculture in what was then Belgian Congo. After Congo's Independence in 1960, Pierre's work continued within the Belgian Institute for Overseas Scientific Research, which included the elaboration of a large collection of herbarium specimens. This work was published in 1970 as a part of the scientific series of Maps of Soils and Vegetation of Congo ("Cartes des sols et de la végétation du Congo") and was awarded the Emile De Wildeman Price of the Royal Botanical Society of Belgium. His phycological career really started in 1963 when Pierre Compère obtained the position for Algology at the National Botanic Garden of Belgium and started a collaboration with Pierre Bourrelly of the Laboratory for Cryptogamic Botany of the National Museum of Natural History in Paris.

During his career at the Botanic Garden, Pierre has studied the freshwater algal diversity from various regions of the

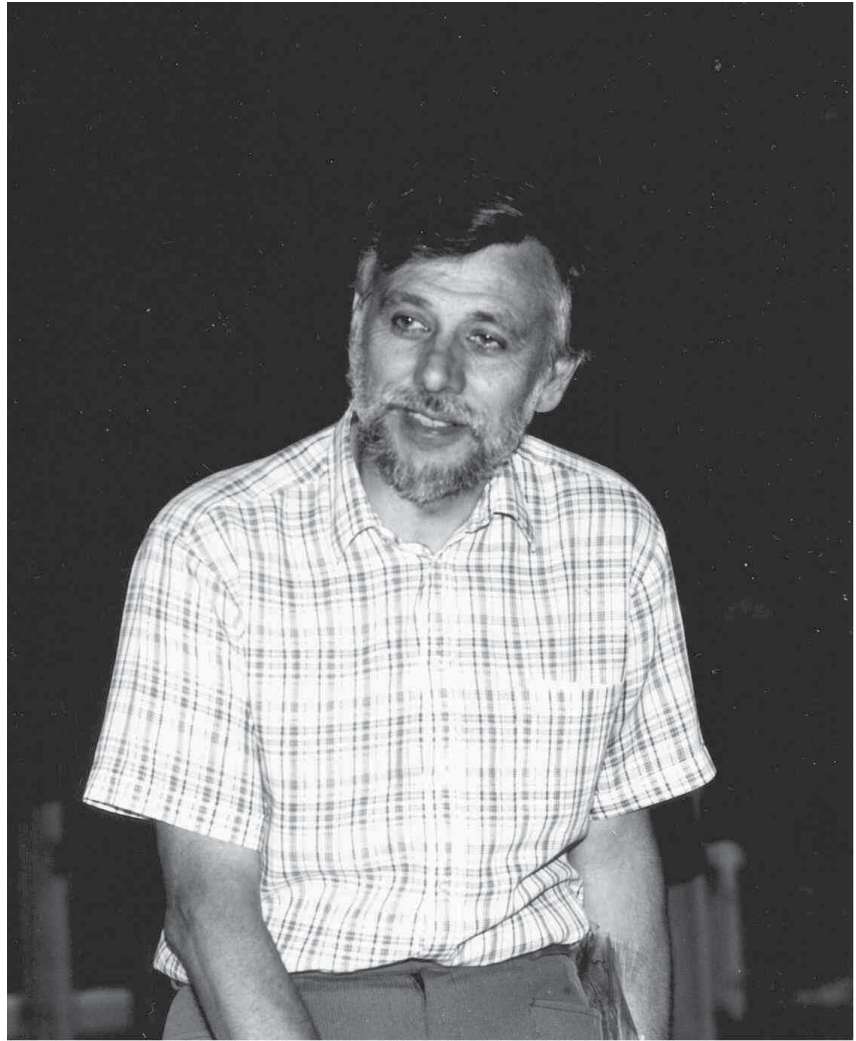

Pierre Compère at the $10^{\text {th }}$ IAC symposium in Athens (Greece) in 1986 (picture by Dr. L. Kovacik). 
world, with a focus on Africa. He has also become a reference for the phycological research in Belgium and published a 'practical flora' for the determination of cyanobacteria of Belgium (Compère 1987).

Pierre's support for diversity and ecology of cyanobacteria, which stemmed from his experiences with freshwater algae and general microflora of tropical countries, notably of the lake Chad, as well as of his native Belgium, has fruitfully contributed to the work of the International Association for Cyanophyte Research (IAC) which organizes Workshops on the diversity and ecology of cyanobacteria for over fifty years. This international group has brought 'botanists' and 'bacteriologists' together, with different traditions reconciled, while the orientation of the IAC Workshops grew more interdisciplinary with time.

The 'founding event' of the IAC Workshops happened at a field trip during the 1959 Limnological Congress in Austria, when 'cyanophiles' assembled on an improvised raft on Traunsee lake. This field trip was organized by two people, who loved the blue-greens and lamented that their everyday occupation did not grant them enough time to dedicate to their favored group of organisms. Edith Kann was a high school biology teacher in Austria and Otto Jaag was the head of the Institute EAWAG at ETH Zürich, that deals with the protection of Swiss lakes and waterways. On that fieldtrip, Professor Jaag announced: "We should get together next year for a working symposium ('Arbeitssymposium', the word for workshop was not yet in fashion) in our just finished limnological field laboratory in Kastanienbaum on the Lake Luzern - you are all invited". So, the first meeting took place there in 1960, and in 1961 again when the IAC was officially founded to continue with workshops every three years. This was a successful initiative as it is still lasting and the $19^{\text {th }}$ International Symposium was organized in 2013 in Cleveland, Ohio (US). A characteristic of these IAC workshops is that they combine field trips, microscopy sessions with active discussions and oral contributions (now also posters). Pierre Compère has attended many of these workshops (see photograph) and we wish to reminisce them jointly at the occasion of his $80^{\text {th }}$ birthday.

In 1972 , the $6^{\text {th }}$ IAC Symposium (still in Kastanienbaum), was honored by the participation of Roger Stanier (see Stanier 1980 for a biography), and his collaborators. As followers of the Bacteriological tradition, their work was based on axenic cultures rather than on field observations. They organized a demonstration display of their cultures under the laboratory microscopes and Roger asked: "You are the experts, please, tell us which organisms do we have in these cultures". This was an unusual task, as was the tone compared with the one usually displayed at the IAC workshops. But the interactions became soon cordial and the exchange of experiences were mutually beneficial. However, a new paradigm was born and would start to influence the way that we view the organisms.

The next surprise came in when Stanier et al. (1978) proposed that cyanobacteria, being prokaryotes, be placed under jurisdiction of the Bacteriological Code of Nomenclature, because they were bacteria, after all. Till then, the organisms' nomenclature was governed by the Botanical code, which historically governed the nomenclature rules of all phototrophic organisms. It was Stanier \& van Niel (1962) who earlier had synonymized the terms 'prokaryotes' (a structural definition) with 'Bacteria' (a taxon), and introduced the term 'Cyanobacteria'. Some botanists joined this proposal, but others objected, often on ecological grounds. The discussions were sometimes passionate and difficult. Pierre Compère played a role because of his deep knowledge of the rules and regulations of the Botanical Code of Nomenclature. He was interested since a long time by nomenclatural questions, as demonstrated by his list of publications (see Fabri $\&$ Symoens 2000) and his nomination as the Secretary of the Nomenclature Committee for Algae of the International Association for Plant Taxonomy (IAPT). Therefore, Pierre has led the discussion that clarified and justified the applicability of the Botanical Code to this group of prokaryotic photosynthesizers, because they were functionally competing and sharing the same ecological niches with eukaryotic algae.

It can be noted that the distinction between the cyanobacteria and other organisms has already been drawn in the $19^{\text {th }}$ century. As vividly recalled by Drews (2000), it was Ferdinand Julius Cohn, a botanist and microbial ecologist, who coined a pair of names: 'Schizophyceae' and 'Schizomycetes', to characterize cyanobacteria as distinct from other, nonphototrophic bacteria. That way, he spelled out clearly his understanding of the prokaryotic nature and organization of those organisms that divide by fission instead of mitosis. His terms meant literally 'splitting algae' referring to the cell fission of cyanobacteria and 'splitting fungi', referring to the same process in bacteria, which were similar to fungi by not being able to perform the 'plant kind' of photosynthesis. He placed them both in one phylum, 'Schizophyta', as a part of the Plant Kingdom. Indeed, in his time, all living beings were classified in only two kingdoms!

The involvement of Pierre Compère in the resolution of nomenclatural problems has taken a wider dimension with the present-day discussion to harmonize the rules of the two codes which deal with the nomenclature of cyanobacteria, the International Code of Nomenclature of Prokaryotes (http://www.bacterio.net/-foreword.html\#Code) (ICNP) and the International Code of Nomenclature for algae, fungi, and plants (http://www.iapt-taxon.org/nomen/main.php) (called 'Botanical code'). The Proceedings of the $16^{\text {th }}$ Symposium of the IAC in Luxemburg in 2004 (Hoffmann et al. 2005) give a vivid account of the talks and debates on this subject. Pierre contributed a presentation of the rules and principles of the Botanical code and their application to cyanobacteria. In particular, the typification, the valid publication of new names and the assessment of the validity of old names were discussed (Compère 2005). One of the proposals that came out of this workshop was the preparation by the 'botanists' of a list of approved names of genera and species, with consideration of their types, to serve as a new starting point for nomenclature (Hoffmann 2005). However, it was quite obvious that such a process should be conducted in collaboration with the 'bacteriologists', of whom some were also present at that IAC workshop (Oren \& Tindall 2005). At the bacterial side, the structure that is dealing with the taxonomy and nomenclature of cyanobacteria is the Subcommittee on the Taxonomy of Phototrophic Bacteria of the International 
Committee on Systematics of Prokaryotes (e.g. Madigan \& Imhoff 2007).

At the end of 2011, a Special Committee on Harmonization of Nomenclature of Cyanophyta/Cyanobacteria was established by the IAPT, and included both 'botanists' (with Pierre Compère) and 'bacteriologists' (McNeill et al. 2011). Its mandate is to consider ways to harmonize the nomenclature and avoid multiple names for the same organism. It should report to the Nomenclature Section of the XIX ${ }^{\text {th }}$ International Botanical Congress in July 2017. The task ahead is not easy, but of great importance for the progresses in cyanobacterial studies.

Many things have changed since the early days of Pierre Compère's career but just as many questions remain. What has changed is the insight that the traditional research disciplines cannot solve the problems alone any longer and require interdisciplinary and often international collaborations. Rapid advancements in research tools enabled an unprecedented access to scientific data, which now requires additional technology to handle that information. But the advancements were also possible because some early hypotheses were technologically confirmed and opened several fundamental insights. Documentation, modification and new interpretation of Wegener's Continental Drift theory gave rise to plate tectonics. The recognition of DNA as the molecule of the genetic code in the 1950s, and the subsequent ability of gene sequencing opened a new basis to assess the organismal diversity. The confirmation in the 1960s that Precambrian is fossiliferous started intensive research of microbial fossils, especially the early fossils of cyanobacteria. The classification of living beings moved from two to five kingdoms (Whittaker \& Margulis 1978) and then to three domains (Woese 1987). In the latter, the Prokaryotes are including two domains of Life and are now no longer synonymous with bacteria. While we used to wonder at one time whether the cyanobacteria are algae, we have learned since, through molecular confirmation of the Endosymbiotic Theory (Mereschkowsky 1910, Sagan 1967), that the algae and plants derived their basic energy management from cyanobacteria who are the sole monophyletic source of oxygenic photosynthesis (Falkowski et al. 2004).

What did not change is the proportion of uncertainties associated with the information increase due to the use of all those technological improvements. In fact, we realize the need to stay modest and critically accept the "relativity of truth", when obtained through the 'filters' of various instruments, techniques and measures, with each piece of information intimately associated with method-specific artifacts. Taxonomic research is such an endeavour, and Pierre Compère stayed remarkably modest in this respect.

The cyanobacterial systematics today continues by the use of a 'polyphasic' taxonomy, in which molecular taxonomic markers are combined and compared with morphological and ecological information (Vandamme et al. 1996, Komárek 2006). The future beyond the present state should strive toward an increase of taxonomic resolution of the genetic markers, including the understanding of the controls that govern the organismal activities and responses. The final goal would be to understand which genotypic markers are responsible for the morphological developments and thus the phenotypic characters used in taxonomy. We hope that Pierre Compère will still accompany these new developments for many years.

\section{ACKNOWLEDGEMENTS}

We want to thank our colleagues in cyanobacterial systematics, who makes this discipline so enjoyable and interesting, especially Pierre Compère for his kindness, patience and good advices. A. Wilmotte is Research Associate of the National Fund for Scientific Research of Belgium (FRS-FNRS). S. Golubic had a scientific fellowship of the FRS-FNRS of Belgium to work at the University of Liège.

\section{REFERENCES}

Compère P. (1987) Flore pratique des algues d'eau douce de Belgique. I. Cyanophyceae. Meise, Jardin Botanique National de Belgique.

Compère P. (2005) The nomenclature of Cyanophyta under the Botanical Code. Algological Studies 117: 31-37. http://dx.doi. org/10.1127/1864-1318/2005/0117-0031

Drews G. (2000) The roots of microbiology and the influence of Ferdinand Cohn on microbiology of the 19th century. FEMS Microbiology Reviews 24: 225-249. http://dx.doi. org/10.1111/j.1574-6976.2000.tb00540.x

Fabri R., Symoens J.J. (2000) Pierre Compère, de la carte de végétation du Bas-Congo au secrétariat du comité pour la nomenclature des algues. Systematics and Geography of Plants 70 : 227-233.

Falkowski P.G., Katz M.E., Knoll A.H., Quigg A., Raven J.A., Schofield O., Taylor F.J. (2004) The evolution of modern eukaryotic phytoplankton. Science 305: 354-360. http://dx.doi. org/10.1126/science.1095964

Hoffmann L. (2005) Nomenclature of Cyanophyta/Cyanobacteria: roundtable on the unification of the nomenclature under the Botanical and Bacteriological Codes. Algological Studies 117: 13-29. http://dx.doi.org/10.1127/1864-1318/2005/0117-0013

Hoffmann L., Komárek J., Lhotsky O. (eds) (2005) Proceedings of the 16th Symposium of the International Association for Cyanophyte Research (IAC), Luxemburg (Luxemburg) 2004. Algological Studies 117.

Komárek J. (2006) Cyanobacterial taxonomy: current problems and prospects for the integration of traditional and molecular approaches. Algae 21: 349-375. http://dx.doi.org/10.4490/algae.2006.21. 4.349

Madigan M.T., Imhoff J.F. (2007) International Committee on Systematics of Prokaryotes. Subcommittee on the taxonomy of phototrophic bacteria. Minutes of the meetings, $29 \mathrm{Au}-$ gust 2006, Pau, France. International Journal of Systematic and Evolutionary Microbiology 57: 1169-1171. http://dx.doi. org/10.1099/ijs.0.65116-0

McNeill J., Turland N.J., Monro A.M., Lepschi B.J. (2011) Preliminary mail vote and report of Congress action on nomenclature proposals. Taxon 60: 1507-1520.

Mereschkowsky K. (1910) Theorie der zwei Plasmaarten als Grundlage der Symbiogenesis, einer neuen Lehre von der Entstehung der Organismen. Biologisches Centralblatt 30: 353-367.

Oren A., Tindall B.J. (2005) Nomenclature of the cyanophyta/ cyanobacteria/cyanoprokaryotes under the International Code 
of Nomenclature of Prokaryotes. Algological Studies 117: 3952. http://dx.doi.org/10.1127/1864-1318/2005/0117-0039

Sagan L. (1967) On the origin of mitosing cells. Journal of Theoretical Biology 14: 225-274. http://dx.doi.org/10.1016/00225193(67)90079-3

Stanier R.Y., van Niel C.B. (1962) The concept of a bacterium. Archiv für Microbiologie 42: 17-35. http://dx.doi.org/10.1007/ BF00425185

Stanier R.Y., Sistrom W.R., Hansen T.A., Whitton B.A., Castenholz R.W., Pfennig N., Gorlenko W.N., Kondratieva E.N., Eimhjellen K.E., Whittenbury R., Gherna R.L., Trüper H.G. (1978) Proposal to place the nomenclature of the cyanobacteria (blue-green algae) under the rules of the International Code of Nomenclature of Bacteria. International Journal of Systematic Bacteriology 28: 335-336. http://dx.doi.org/10.1099/0020771328-2-335
Stanier R.Y. (1980) The journey, not the arrival matters. Annual Review of Microbiology 34: 1-48. http://dx.doi.org/10.1146/ annurev.mi.34.100180.000245

Vandamme P., Pot B., Gillis M., de Vos P., Kersters K., Swings J. (1996) Polyphasic taxonomy, a consensus approach to bacterial systematics. Microbiological Reviews 60: 407-438.

Whittaker R.H., Margulis L. (1978) Protist classification and the kingdoms of organisms. BioSystems 10: 3-18. http://dx.doi. org/10.1016/0303-2647(78)90023-0

Woese C.R. (1987) Bacterial evolution. Microbiological Reviews 51: 221-271.

Manuscript received 31 Jul. 2014; accepted in revised version 9 Sep. 2014.

Communicating Editor: Elmar Robbrecht. 